


\title{
Painting
}

\section{WITH LIGHT}

\author{
JOHN ALTON
}

New Foreword by John Bailey

Introduction by Todd McCarthy

曲

UNIVERSITY OF CALIFORNIA PRESS

Berkeley Los Angeles London 
University of California Press, one of the most distinguished university presses in the United States, enriches lives around the world by advancing scholarship in the humanities, social sciences, and natural sciences. Its activities are supported by the UC Press Foundation and by philanthropic contributions from individuals and institutions. For more information, visit www.ucpress.edu.

The publisher gratefully acknowledges the contribution provided by the General Endowment Fund of the Associates of the University of California Press.

University of California Press

Berkeley and Los Angeles, California

University of California Press, Ltd.

London, England

(1) 1995, 2013 by The Regents of the University of California

ISBN: 978-0-520-27584-3

The 1995 edition was catalogued by the Library of Congress as follows:

Library of Congress Cataloging-in-Publication Data

Alton, John.

Painting with light / John Alton.

p. $\quad \mathrm{cm}$.

Originally published: New York: Macmillan, 1949. With new

introductory material and filmography.

Includes index.

Filmography: p.

ISBN: 0-520-08949-9 (alk. paper: pbk.)

1. Cinematography-Lighting. 2. Alton, John. I. Title.

TR891.A48 1995

$779.5^{\prime} 343-\mathrm{d} c 20$

94-44121

CIP

Manufactured in the United States of America

$\begin{array}{llllll}22 & 21 & 20 & 19 & 18 & 17\end{array}$

$\begin{array}{lllllllll}10 & 9 & 8 & 7 & 6 & 5 & 4 & 3\end{array}$

The paper used in this publication meets the minimum requirements of ANSI/NISO Z39.48-1992 (R 2002) (Permanence of Paper). 
TO MY DEAR WIFE Rozalia

whose infinite patience and encouragement made this book possible. 
Life is short, but long enough to get what's coming to you.

THE AUTHOR 